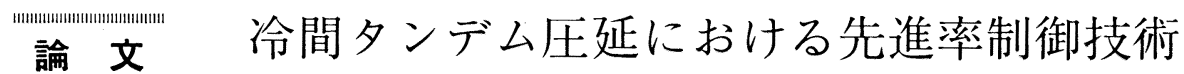 の開発
}

\author{
山本 普康 $*$ ・橋本 淳*2・新留 照英*2 \\ 白石 利幸 $* 3 \cdot$ 浅村 峻*2
}

\section{Development of Forward Slip Ratio Control in Tandem Cold Rolling}

\author{
Hiroyasu Yamamoto, Jun Hashimoto, Teruhide Nidome, \\ Toshiyuki SHIRAISHI and Takashi AsAmura
}

\begin{abstract}
Synopsis :
In order to achieve the high productivity in a continuous tandem cold mill, the control system of forward slip ratio has been developed by the use of a supply device of rolling lubricant, which works in quick response to the lubricant flow and concentration.

In the calculation model of this control system, the method which modifies BLAND \& FoRD's equation with a slide factor for calculation of friction coefficients is used to estimate negative values of forward slip ratio in addition to positive values. As for the supply device of rolling lubricant, emulsion stability and particle size distribution of lubricant obtained by a static mixer are equivalent to those by a convenient device. A high-speed and stable rolling without chattering can be realized by controlling the supply amount of rolling lubricant in the present control system of forward slip ratio.

Key words : cold rolling; lubrication; friction coefficient; modelling; forward slip ratio ; chattering ;
\end{abstract} rolling; process control.

\section{1. 緒}

\section{言}

連続式冷間タンデムミルにおいて高生産性機能を十分 に発揮するためには，安定した高速压延を実現すること が必要である．冷間圧延における压延不安定現象の一つ に, 多量のコイルを同一ロールで圧延していくと, ロー ル周速度と板速度とが等しくなる中立点位置がロールバ イト出口に移動し, ついにはロールバイトより外に出て チャタリング1) が発生する現象がある. 極薄用冷間圧延 ミルである八幡 4 冷延では，このような中立点変動に起 因した圧延不安定現象を防止するために，圧延潤滑油の 流量と濃度とを高㐫答で変更できる潤滑供給装置を用 い, 先進率（式（1）参照）を安定圧延領域に制御でき る先進率制御システムを開発した。本報告では,このシ ステムに組み込まれている先進率予測モデル，およびこ のシステムに用いられている制御装置とこの装置を用い て行つた実験の結果について説明する。 なお，先進率制 御システムは八幡 4 冷延の第 6 スタンドに組み込まれて
いるが, 先進率子測モデルの精度検証は, 第 6 スタンド に加えて第 1 スタンドでも行つた。

\section{2. 先進率の挙動}

安定压延の指標として用いられる先進率 $f_{s}$ は, 压延 出側の板速度を $V_{0}$, ロール周速度を $V_{R}$ とすると, 次 式で与えられる。

$$
f_{s}=\frac{V_{0}}{V_{R}}-1
$$

Fig. 1 は, 八幡 4 冷延の第 6 スタンド（最終スタンド, $\mathrm{NH} \cdot 6 \mathrm{Hi}$ ミル2) ) で普通鋼を压延した時の先進率の推移 を示す.ここで，原板板厚 $H_{0}$ は $2.3 \sim 3.0 \mathrm{~mm}$, 第 6 ス タンドにおける圧延出側の板厚 $h_{6}$ は $0.2 \sim 0.3 \mathrm{~mm}$, 圧 下率 $r_{6}=\left(H_{6}-h_{6}\right) / H_{6}$ は $0.25 \sim 0.35\left(H_{6}\right.$ は压延入側 の板厚), 压延速度 $V_{R_{6}}$ は $1800 \sim 2000 \mathrm{~m} / \mathrm{min}$ である. ワークロールは, ロール径が $\phi 440 \mathrm{~mm}$ で, 初期表面粗 度が $0.28 \mu \mathrm{mRa}$ のブライトロールである. 先進率は,

Fig. 2 に示すように, 各压延スタンドの出側にあるガ

昭和 61 年 4 月本会講演大会にて発表 昭和 61 年 8 月 28 日受付 (Received Aug. 28, 1986)

* 新日本製鉄 (株)八幡製鉄所 (現: 新日本製鉄 (株) 塑性加工研究センター) 工博 (Yawata Works, Now Material

Forming Process Lab., Nippon Steel Corp., 1-1-1 Edamitsu Yahatahigashi-ku Kitakyushu 805)

*2 新日本製鉄 (株) 八幡製鉄所 (Yawata Works, Nippon Steel Corp.)

*3 新日本製鉄 (株) 塑性加工研究センター (Material Forming Process Lab., Nippon Steel Corp.) 


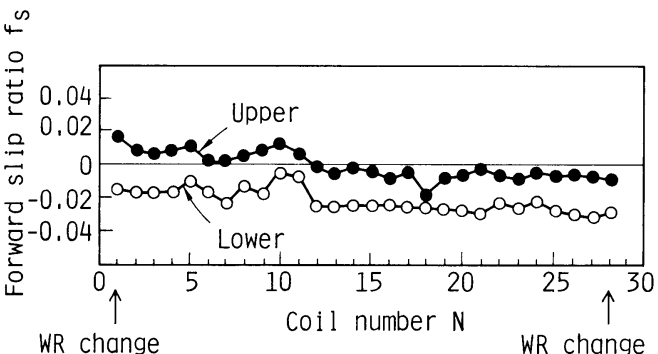

Fig. 1. Transition of forward slip ratio at No. 6 stand in the cold tandem mill.

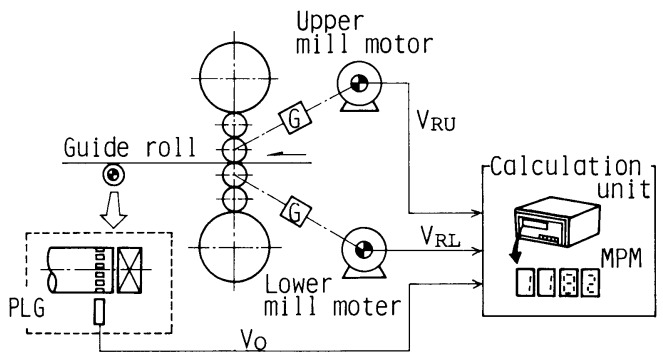

Fig. 2. Schematic diagram of the measuring device of forward slip ratio.

イドロールの楇速度から求められた极速度とミルモー ターの回転数から求められたロール周速度とによつて計 算され，各コイルごとに尤延が尘常になつた時から 50 $\mathrm{ms}$ の墧期で計算された 10 点の值の平均值で与えられ ている. なお，このガイドロールオ式による第 6 スタン ドの先進率の測定値とロールにケガキ線を人れて压延し た板から測定した第 6 スタンドの先進率 ${ }^{3)}$ の值との比較 を Fig. 3 に示す.ガイドロール方式による先進率の值 は，压延した板から測定した值と $\pm 0.5 \%$ の範讲で一 致している. また，4冷延は各スタンドとも上下のワー クロールがそれぞれ独立のモーターで駆動されているた め, Fig. 1 に示した先進率の值はワークロール上下で 若干異なつている.

先進率は压延の進行に従つて減少し, 先進率の值が上 下ともに負であつても安定して压延できることが分か る. 先進率が鱼となる現象は, テストミルでの実験結 果到にも報告されており，また压延中に权表面に発生す るロール疵のピッチがロール川㓮よりも短いことからも 裏付けられる。.なお，4冷延ではワークロール上下で先 進率の值が異なつているため, 以後の先進率の值には ワークロール上下の平均値を用いる。

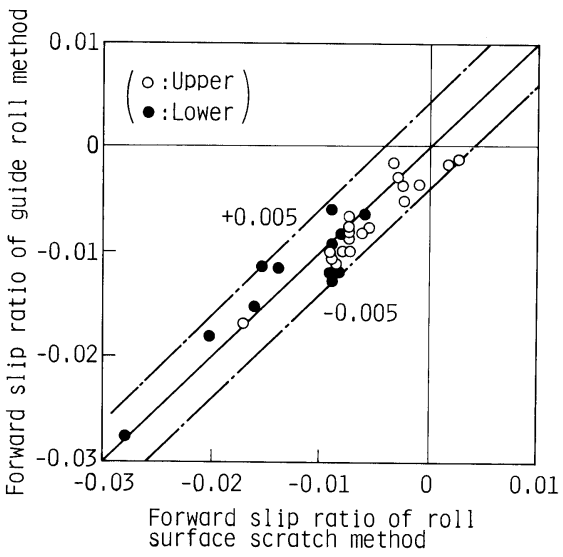

Fig. 3. Comparison between roll surface scratch method and guide roll method for forward slip ratio.

\section{3. 先進率予測モデル}

\section{$3 \cdot 1$ 摩擦係数および 2 次元平均変形抵抗の予測式}

先進率は压延要因（例えば板厚, 張力, ロール粗度な ど）によつて複雑な挙動を示すことが, 実験や数值解析 によつて知られている ${ }^{5)}$. そこで，ここでは比較的压延 要因との関係が明確なワークロールと板との間の摩擦係 数で予測式を組み立て，スライド係数を用いて BLAND \& FORD の先進率式6) を補正した式によつて先進率を予測 する。

最初に，摩擦係数の予測に用いる重回帰式の形を決め るため, 摩擦係数 $\mu$ と主要な压延要因（压下率 $r$, 後力 張力 $\sigma_{b}$, 压延速度 $V_{R}$, ロール替えからの压延した重量 $W$, 压延潤滑油量 $Q$ (流量 $\times$ 濃度の正味油量を示す) との関係を実験用圧延機および冷間タンデムミルで明ら かにした。摩擦係数は, BLAND \& FORD の式の厳密式で ある OROWAN のモデル7) からなる压延解析モデル8) を用 いて先進率法 ${ }^{8)}$ で求めた。な㧍，压延実験の条件は汹中 に示してある。网中の $D_{W}$ はワークロール往，Hは底: 延入側の板厚, $\sigma_{f}$ は前方張力, $\bar{\sigma}$ は相当心力, $\bar{\varepsilon}$ は相 当ひずみである.

摩擦係数に及ぼす压下率の効果を Fig. 4 に，後方張 力の効果を Fig. 5 に, 圧延速度の効果を Fig. 6 に, ロー ル替えからの压延した重量の効果を Fig. 7 に，压延潤 滑油量の効果を Fig. 8 に示す。摩擦係数は压下率求よ び後方張力の増加とともにほぼ直線的に増大し, 压延速 度，圧延した重量および圧延潤滑油量の増加とともに指 数関数的に減少している。ここで，压下率と压延速度の 効果は油膜厚式9) からも十分に予想される傾向であり， 


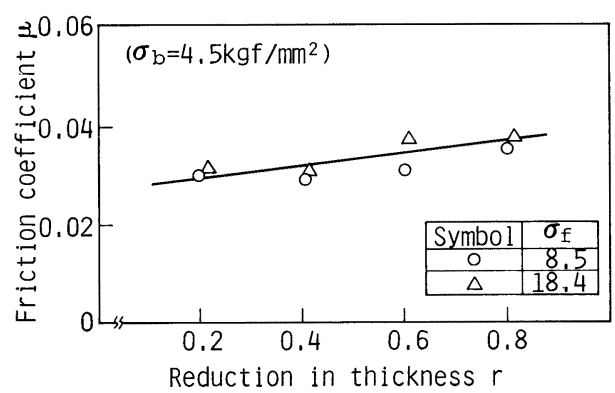

$D_{W}=\phi 165 \mathrm{~mm}, H=0.8 \mathrm{~mm}, V_{R}=10 \mathrm{~m} / \mathrm{min}$ Material : SPCC, $\bar{\sigma}=66.0 \overline{(\varepsilon+0.0077)^{0.208}}$

Lubrication : $3 \%$ emulsion of fat oil, $60^{\circ} \mathrm{C}$

Roll surface roughness : $0.2 \mu \mathrm{m} \mathrm{Ra}$

Fig. 4. Effect of reduction in thickness on friction coefficients.

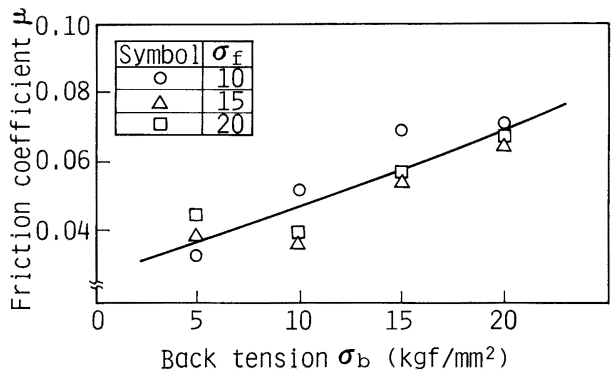

$D_{W}=\phi 165 \mathrm{~mm}, H=0.8 \mathrm{~mm}, V_{R}=10 \mathrm{~m} / \mathrm{min}, r=0.4$

Material : SPCC, $\bar{\sigma}=67.5 \overline{(\varepsilon}+0.0096)^{0.206}$

Lubrication : $5 \%$ emulsion of fat oil, $60^{\circ} \mathrm{C}$

Roll surface roughness : $0.8 \mu \mathrm{m} \mathrm{Ra}$

Fig. 5. Effect of back tension on friction coefficients.

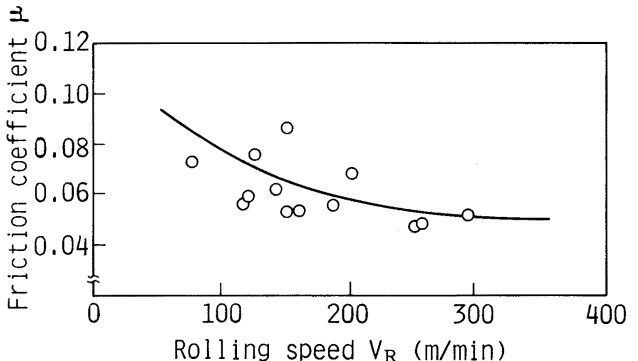

$D_{W}=\phi 320 \mathrm{~mm}, H=3.0 \mathrm{~mm}, \sigma_{b}=0.5 \mathrm{kgf} / \mathrm{mm}^{2}$

$\sigma_{f}=5 \sim 10 \mathrm{kgf} / \mathrm{mm}^{2}, r=0.25 \sim 0.4$

Material : High strength carbon steel

$\bar{\sigma}=81.5(\bar{\varepsilon}+0.0046)^{0.156}$

Lubrication : $3 \sim 3.5 \%$ emulsion of fat oil

Roll surface roughness : $1.8 \mu \mathrm{m} \mathrm{Ra}$

Fig. 6. Effect of rolling speed on friction coefficients.

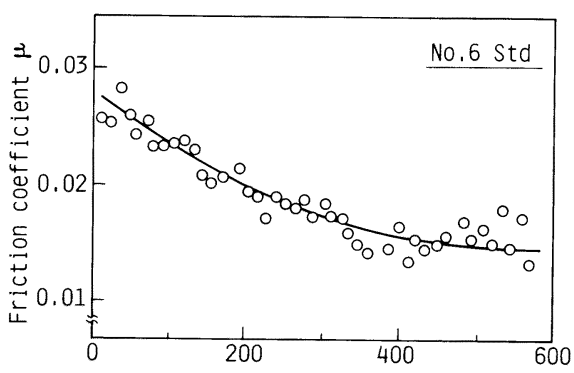

Rolled coil weight w (ton)

$D_{W}=\phi 410 \mathrm{~mm}, H_{0}=2.5 \sim 3.0 \mathrm{~mm}$ at No. $1 \mathrm{Std}$

$\sigma_{b} \fallingdotseq 5 \mathrm{kgf} / \mathrm{mm}^{2}, \sigma_{f} \fallingdotseq 10 \mathrm{kgf} / \mathrm{mm}^{2}, r=0.2 \sim 0.25, V_{R}=1000 \sim 1500$ $\mathrm{m} / \mathrm{min}$

Material : Carbon steel, $\bar{\sigma}=77.0(\bar{\varepsilon}+0.0046)^{0.216}$

Lubrication : palm oil (neat)

Roll surface roughness : $0.9 \mu \mathrm{m} \mathrm{Ra}$

Fig. 7. Effect of rolled coil weight from roll change on friction coefficients.

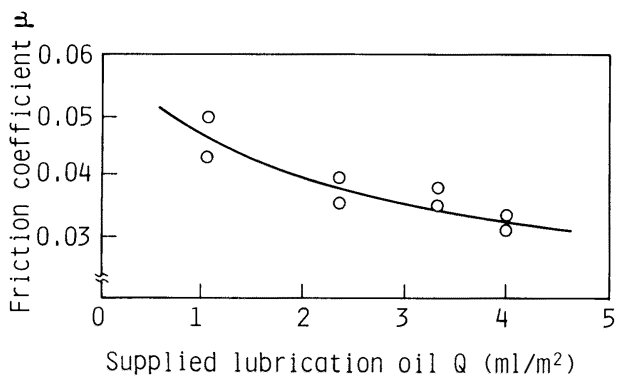

Experimental conditions: The same as those of Fig. 5 with lubrication $5 \%$ emulsion of fat oil

Fig. 8. Effect of supplied lubrication oil on friction coefficients.

既に報告されている実験結果 ${ }^{10) 11)}$ とも傾问的に一致す る。また，压延した重量の効果は压延の進行とともに生 ずるロール粗度の減少に起因すると考えられ，压延潤滑 油量の効果は潤滑油のプレートアウト量の増加に起因す ると推察される。これらの結果から，摩擦係数予測式に 取り込む各压延要因の式の形としては, 压下率 $r=(H-h)$ $/ H[-]$ および後方張力 $\sigma_{b}\left[\mathrm{kgf} / \mathrm{mm}^{2}\right]$ に関しては一次 式で, 圧延速度 $V_{R}[\mathrm{~m} / \mathrm{min}]$, ロール替えからの压延し た重量 $W[\mathrm{t}]$ （または長さ $L[\mathrm{~m}]$ ）および压延潤滑油 量 $Q\left[\mathrm{ml} / \mathrm{m}^{2}\right]$ に関しては指数関数で与えることができ る.さらに，上記以外の压延要因で摩擦係数に影響を及 ぼすと考えられるものは，压延入側の板厚 $H[\mathrm{~mm}]$ ，压 延出側の板厚 $h[\mathrm{~mm}]$, 前方張力 $\sigma_{f}\left[\mathrm{kgf} / \mathrm{mm}^{2}\right], 2$ 次元 平均变形抵抗值 $k\left[\mathrm{kgf} / \mathrm{mm}^{2}\right]$, および次式で与えられる スリップ率 $\Delta V / V_{R}{ }^{12)}$ (ワークロールと板との間のス リップの大きさ） [-] がある. 


$$
\frac{\Delta V}{V_{R}}=\frac{f_{s}{ }^{2}+f_{b}{ }^{2}}{2\left(f_{s}+f_{b}\right)}, f_{b}=1-\left(f_{s}+1\right)(1-r) \cdots(2)
$$

これらはいずれも先に述べた指数関数型の圧延要因に比 べると, 変動がはるかに小さいため, 式の形としては一 次式で与えてさしつかえないと考えられる. 以上から， 摩擦係数予測式 $\mu^{*}$ には次式で書き表される重回帰式を 用いる。

$$
\begin{aligned}
\mu^{*} & =A_{v} e^{-B_{v} v_{R}}+A_{L} e^{-B_{L} L}+A_{Q} e^{-B_{Q}^{Q}}+A_{r} r+A_{H} H \\
& +A_{h} h+A_{b} \sigma_{b}+A_{f} \sigma_{f}+A_{k} k+A_{d} \frac{\Delta V}{V_{R}}+\mu_{0} \cdots
\end{aligned}
$$

ここで, $B_{v}, B_{L}$ および $B_{Q}$ はあらかじめ Fig. 6〜8 に 示した実験によつて求められる定数であり, $A_{v}, A_{L}$, $A_{Q}, A_{r}, A_{H}, A_{h}, A_{b}, A_{f}, A_{k}, A_{d}$ および $\mu_{0}$ は重回帰に よつて求められる定数である. なお, 式 (3)の $\mu^{*}$ は, 後で詳しく述べるように, スライド係数で補正され て求められた摩擦係数であり, $\mu^{*}$ に対する各压延要因 の影響は Fig. 4〜Fig. 8 に示した傾问と闹一である.

次に, 摩擦係数を求める力法について述べる. 一般に, 圧延不安定現象が発生する近傍の先進率は, Fig. 1 に 示したように負になることが多い。一方, 先進率が負の 場合で摩擦係数を求める方法拉よびその逆を計算する方 法は, 現在まだ確立されていない。そこで,ここではオ ンラインに組込みが叮能な簡易モデルにすることを考慮 して, スライド係数を用いて BLAND \& F ORD の先進率 式6)補正する以下の方法を採用した。

まず, 摩擦係数の算出に用いる 2 次元平均変形抵抗值 $k$ は, 式 (4) に示す Bl.AND \& F ORD の式と式 (5)に 示す HLL の圧延荷重式 ${ }^{13) 14)}$ とを連立させて求める.

$$
\left.\begin{array}{l}
\tan ^{2}\left(\sqrt{\frac{h}{R^{\prime}}} \frac{H_{n}}{2}\right)=f_{s}^{\prime}, \\
H_{n}=\sqrt{\frac{R^{\prime}}{h}} \tan ^{-1}\left(\sqrt{\frac{H-h}{h}}\right) \\
-\frac{1}{2 \mu} \ln \left(\frac{H}{h} \frac{1-\sigma_{f} / k}{1-\sigma_{b} / k}\right) \\
\text { ただし, } f_{\text {s.mea }} \geqq 0 \text { の時 } f_{s}^{\prime}=f_{s \cdot \text { mea }} \\
f_{\text {s.mea }}<0 \text { の時 } f_{s}^{\prime}=0
\end{array}\right\}
$$

$$
\begin{aligned}
& w K k \sqrt{R^{\prime}(H-h)} \\
& \times\left(1.08+1.79 r \sqrt{1-r} \mu \sqrt{\frac{R^{\prime}}{h}}-1.02 r\right) \\
& =P_{\text {mea }} \\
& K=1-\frac{0.7 \sigma_{b}+0.3 \sigma_{f}}{k}, \\
& R^{\prime}=R\left[1+\frac{16\left(1-\nu^{2}\right)}{\pi E} \frac{P_{\text {mea }}}{w(H-h)}\right]
\end{aligned}
$$

ここで, $\mu$ は压延荷重 $P$ を計算するための摩擦係数, $w$
は板幅, $R$ はワークロール半径, $R^{\prime}$ は偏平したロール 半径で Н のポアソン比, $E$ はロールのヤング率であり, 添え字 の $m e a$ は実測值を意味する. 次に, 求めた 2 次元平均 変形抵抗值 $k$ を使い, スライド係数 $C$ を用いて BLAND \& FORD の先進率式 $)^{6)}$ を補正した次式によつて摩擦係数 $\mu^{*}$ を求める.

$$
\begin{gathered}
\tan ^{2}\left(\sqrt{\frac{h}{R^{\prime}}} \frac{H_{n}}{2}\right)=f_{s \cdot m e a}+C, \\
H_{n}{ }^{*}=\sqrt{\frac{R^{\prime}}{h}} \tan ^{-1}\left(\sqrt{\frac{H-h}{h}}\right) \\
-\frac{1}{2 \mu^{*}} \ln \left(\frac{H}{h} \frac{1-\sigma_{f} / k}{1-\sigma_{b} / k}\right)
\end{gathered}
$$

なお, スライド係数の值としては, 式 (6) の $f_{s \cdot \text { mea }}+C$ が常に正となるような值を選べば良い.そのスタンドに おける先進率が負になる場合には, 先進率の最小值より 若干小さい值の絶対值を用い, 先進率が負にならない場 合には 0 を用いる. 式 $(6)$ を解いて $\mu^{*}$ を求めると, 次式が得られる.

$$
\begin{aligned}
\mu^{*} & =\frac{\ln D}{H_{b}-4 \sqrt{\frac{R^{\prime}}{h}} \tan ^{-1} \sqrt{f_{s \cdot m e a}+C}} \\
D & =\frac{H}{h} \frac{1-\sigma_{f} / k}{1-\sigma_{b} / k}, \\
H_{b} & =2 \sqrt{\frac{R^{\prime}}{h}} \tan ^{-1} \sqrt{\frac{H-h}{h}}
\end{aligned}
$$

そして, 摩擦係数の予測式として,この $\mu^{*}$ を用いて前 述した式（3）の形で重回帰式を作成する。ここで，圧 延荷重の計算に使用する $\mu$ は式 (7) で $C=0$ と置い た時の值であるため, $\mu^{*}$ はスライド係数 $C$ だけ増大さ れた摩擦係数值を与える.

一方, 先進率抢上び圧延荷重を予測する際に用いる 2 次元平均変形抵抗の予測式には, 五弓・木原の式 ${ }^{16)}$ のひ ずみ速度と圧延材料温度との効果を圧延速度 $V_{R}$ で代替 した次式を用いる。

$$
k=a(\varepsilon+b)^{n}+c V_{R}, \varepsilon=\ln \frac{H_{0}}{h}
$$

ここで, $H_{0}$ は原板板厚, $h$ は圧延スタンドの出側板厚 であるため, $\varepsilon$ は原板状態から当圧延スタンド出側まで の伸びひずみを与える， $a, b, n$ および $c$ は材料によつ て決まる定数である.一般に, 冷間圧延の材料の 2 次元 平均変形抵抗は, 炭素当量 $C_{e q}[\%]$, 熱間圧延の仕上げ 温度 $T_{F}\left[{ }^{\circ} \mathrm{C}\right]$ および巻取温度 $T_{c}\left[{ }^{\circ} \mathrm{C}\right]$ によつて影響さ れる. そこで, これらの要因を考慮して， $a, n$ および $c$ を次式で示す重回帰式の形で与える. 


$$
\begin{aligned}
& a=\alpha_{0}+\alpha_{1} C_{e q}+\alpha_{2} T_{F}+\alpha_{3} T_{c} \\
& n=\beta_{0}+\beta_{1} C_{e q}+\beta_{2} T_{F}+\beta_{3} T_{c} \\
& c=\gamma_{0}+\gamma_{1} C_{e q}+\gamma_{2} T_{F}+\gamma_{3} T_{c}
\end{aligned}
$$

ここで, $\alpha_{0}, \alpha_{1}, \alpha_{2}, \alpha_{3}, \beta_{0}, \beta_{1}, \beta_{2}, \beta_{3}, \gamma_{0}, \gamma_{1}, \gamma_{2}$, $\gamma_{3}$ は重回帰によつて求められる定数である. また， $k$ に及ぼす $b$ の影響は $a, n$ および $c$ に比べて小さいため に， $b$ を定数 (0.02) で与える. 以上から，2 次元平均 変形抵抗の予測式は, 式 (4) と式 (5) によつて求め られた $k$ を式（8）および式（9）の形で重回帰する ことによつて与えられる.

\section{$3 \cdot 2$ 先進率および圧延荷重の予測計算}

先進率の予測は, 式 (3) で与えられた摩擦係数 $\mu^{*}$ を用いて式（7）を逆に解くことにより，次式で与えら れる.

$$
\begin{gathered}
f_{\text {s.est }}=\tan ^{2}\left(\sqrt{\frac{h}{R^{\prime}}} \frac{H_{n}{ }^{*}}{2}\right)-C \\
H_{n}{ }^{*}=\sqrt{\frac{R^{\prime}}{h}} \tan ^{-1}\left(\sqrt{\frac{H-h}{h}}\right) \\
-\frac{1}{2 \mu^{*}}\left(\frac{H}{h} \frac{1-\sigma_{f} / k}{1-\sigma_{b} / k}\right), \\
R^{\prime}=R\left[1+\frac{16\left(1-\nu^{2}\right)}{\pi E} \frac{P_{\text {est }}}{w(H-h)}\right]
\end{gathered}
$$

ここで，添え字の estは予測值を意味する．また，压延 荷重の予測は, 次式で示すように, 式 (3) で与えられ た摩擦係数 $\mu^{*}$ を圧延荷重用の摩擦係数 $\mu$ に変えた後,

$$
\begin{aligned}
& \mu=\lambda \mu^{*}, \\
& \lambda=\frac{\tan ^{-1} \sqrt{\frac{H-h}{h}}-2 \tan ^{-1} \sqrt{f_{\text {s.est }}+C}}{\tan ^{-1} \sqrt{\frac{H-h}{h}}-2 \tan ^{-1} \sqrt{f_{s}^{\prime}}} \\
& \text { たたし, } f_{s \cdot e s t} \geqq 0 \text { の時 } f_{s}^{\prime}=f_{\text {s.est }} \\
& f_{\text {s.est }}<0 \text { の時 } f_{s}^{\prime}=0
\end{aligned}
$$

HILL の圧延荷重式 ${ }^{13) 14)}$ を用いて, 次式で与えられる.

$$
P_{\text {est }}=w K k \sqrt{R^{\prime}(H-h)}
$$

$$
\times\left(1.08+1.79 r \sqrt{1-r} \mu \sqrt{\frac{R^{\prime}}{h}}-1.02 r\right) \cdots(12)
$$

ここで, $C$ を 0.02 程度にとれば， $\lambda$ は $0.4 \sim 0.7$ 程度 の大きさである。また，式（10）によつて求められた先 進率が限界值を外れている場合に先進率を制御する方法 としては, 式（7）の中の $f_{s \cdot m e a}$ に限界先進率の值を代 入して限界摩擦係数 $\mu^{*}$ を求め, 式（3）の摩擦係数モ デル式から限界摩擦係数を満足するように圧延潤滑油量 $Q$ あるいは压下率 $r$ などを求めてやればよい。 なお, 先進率および压延荷重の予測と, 压延潤滑油量を例にし た先進率制御との計算フローを Fig. 9 に示す. 先進率 と圧延荷重の計算では, 式（3）で示した摩擦係数予測

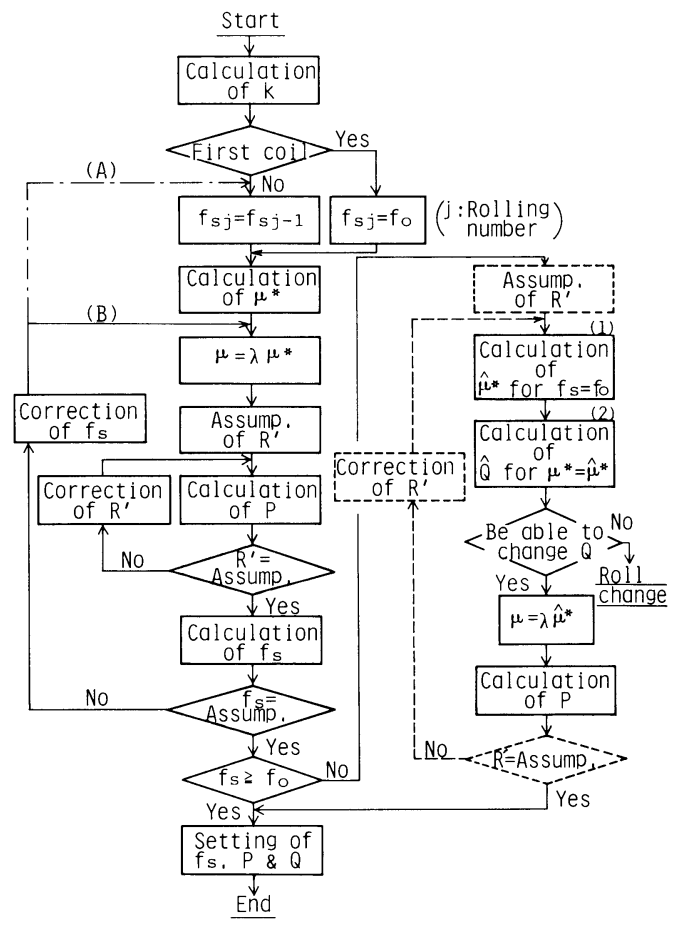

(1) $\hat{\mu}^{*}$ is obtained from eq. (7), (2) $\hat{Q}$ is obtained from eq. (3)

Fig. 9. Calculation flow of forward slip ratio, rolling load and amount of lubrication oil.

式の中の $\Delta V / V_{R} に f_{s}$ が含まれているため, 厳密には 計算フローの中で一点鎖線（A）に従つて計算する必要 がある。しかしこの（A）のフローでは収束計算に NEWTON-RAPHSON 法 ${ }^{17)}$ を用いる必要があり，このため収 束計算に時間がかかつて，オンラインに組み込むには必 ずしも適切でない。一方, 計算フローの中の実線で示し た（B）のフローは，近似計算であるけれど，収束計算 に NEWTON-RAPHSON 法を用いなくても容易に収束し，

（A）のフローに比べて約 $1 / 3$ の計算時間ですむ. しか も，4冷延のように比較的鋼種とサイズがまとまつて圧 延される場合には，精度的にも（A）のフローと同等な 結果が得られる。 なお，先進率制御の計算フローにおい て破線で示された $R^{\prime}$ の収束計算は, その前の過程で求 められた圧延荷重を用いても $R^{\prime} に$ 対してほとんど影響 を及ぼさないため，省略してもさしつかえない．

\section{$3 \cdot 3$ 先進率および圧延荷重の予測精度}

八幡 4 冷延において, Fig. 1 の時と同様な圧延条件 で普通鋼を 126 コイル压延し, 定常压延時のデータか ら 2 次元平均変形抵抗および摩擦係数の予測式を作成し た. 求めた 2 次元平均変形抵抗予測式を次に示す. 


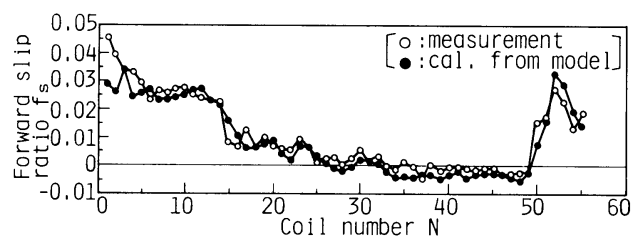

(a) Transition of forward slip ratio

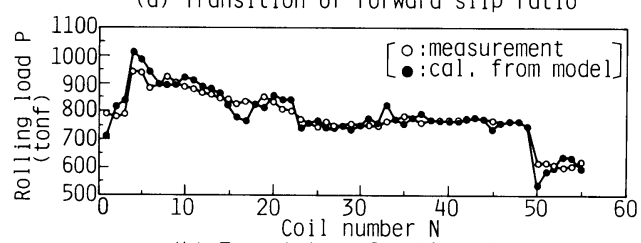

(b) Transition of rolling load

Fig. 10. Comparison between measured values and calculated values for forward slip ratio and rolling load at No. 1 stand in the cold tandem mill.

$$
\begin{aligned}
k_{i}= & a\left(\varepsilon_{i}+0.02\right)^{n}+C V_{R_{i}}, \quad \varepsilon_{i}=\ln \frac{H_{0}}{h_{i}} \\
a & =117.97+0.1623 C_{e q}-0.0276 T_{F} \\
& -0.0392 T_{c} \\
n & =0.5062+2.197 C_{e q}-3.325 \\
& \times 10^{-4} T_{F}+9.234 \times 10^{-5} T_{c} \\
c & =-8.099 \times 10^{-3}+6.508 \\
& \times 10^{-6} C_{e q}+1.439 \times 10^{-5} T_{F} \\
& +2.145 \times 10^{-6} T_{c}
\end{aligned}
$$

ここで，添え字:の $i$ は第 $i$ スタンドを意味する，また， 第 1 スタンドおよび第 6 スタンドの摩擦係数予測式 $\mu_{1}{ }^{*}$ および $\mu_{6}^{*}$ を次に示す.

$$
\begin{aligned}
\mu_{1}^{*} & =1.42 \times 10^{-2} e^{-0.0037 V_{R_{1}}+2.77} \\
& \times 10^{-3} e^{-0.45 Q_{1}}+2.31 \times 10^{-1} e^{-0.001 L_{1}} \\
& +1.71 \times 10^{-1} r_{1}+8.96 \times 10^{-2} H_{1} \\
& -1.21 \times 10^{-1} h_{1}-1.22 \times 10^{-3} \sigma_{b_{1}} \\
& -1.44 \times 10^{-3} \sigma_{f_{1}}-1.15 \times 10^{-4} k_{1} \\
& -8.31 \times 10^{-1} \Delta V_{1} / V_{R_{1}}-1.41 \times 10^{-1} \\
\mu_{6}^{*} & =4.40 \times 10^{-2} e^{-0.0037 v_{R_{6}}+2.92} \\
& \times 10^{-3} e^{-0.45 Q_{6}}+3.46 \times 10^{-4} e^{-0.001 L_{6}} \\
& +1.47 \times 10^{-1} r_{6}+9.45 \times 10^{-2} H_{6} \\
& -9.42 \times 10^{-2} h_{6}+3.29 \times 10^{-3} \sigma_{b_{6}} \\
& -3.14 \times 10^{-4} \sigma_{f_{6}}-1.98 \times 10^{-5} k_{6} \\
& -4.28 \times 10^{-1} \Delta V_{6} / V_{R_{6}}+2.83 \times 10^{-2}
\end{aligned}
$$

ここで, 添え字:の1は第1 スタンドを，6は第 6 スタン ドを意味する．なお， $\mu_{1}{ }^{*}$ を求めた時のスライド係数に は 0.01 を用い, $\mu_{6}^{*}$ の時には 0.03 を用いた。

次に，予測式を求めた時のコイルとは別のコイルを Fig. 1 の時と同様な压延条件で压延し，定常压延時に おける各コイルの先進率および压延荷重の実測値と, 式

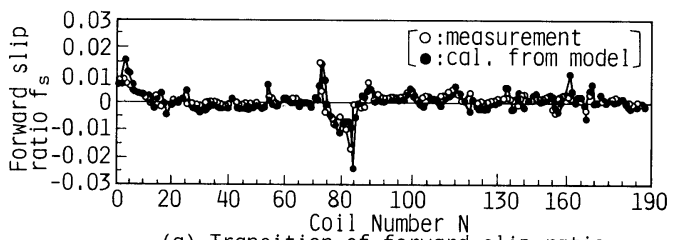

(a) Transition of forward slip ratio

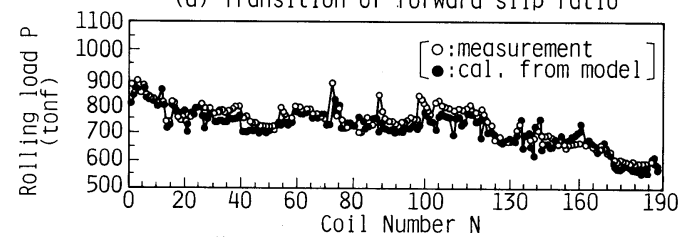

(b) Transition of rolling load

Fig. 11. Comparison between measured values and calculated values for forward slip ratio and rolling load at No. 6 stand in the cold tandem mill.

（13）および式（14）の予測式を用いて計算した各コイ ルの予測值とを比較した。なお, 計算には Fig. 9 の中 で近似計算フローである（B）のフローを用いた．Fig. 10 は，第 1 スタンドにおいて先進率および圧延荷重の 実測值（白丸）と計算値（黒丸）とを圧延コイル順に比 較した図である。Fig. 11 は，第 6 スタンドにおける同 様な比較図である。これらの結果から, 先進率の予測值 は実測値とほほ \pm 0.005 の範囲で一致し, 圧延荷重の 予測値は実測值と $\pm 10 \%$ の精度で一致することが分か る.

\section{4. 先進率制御システムと制御効果}

\section{$4 \cdot 1$ 先進率制御システム}

先進率制御システムに用いられている潤滑制御装置 は, 安定圧延の指標ならびに予測モデルの学習に使用す るための先進率測定装置と, 圧延潤滑油の流量と濃度を 高応答で変更できる潤滑可変装置とからなつている. 先 進率測定装置は，Fig. 2 に示したように，ガイドロー ル方式の板速度計とワークロールに PLG（Pulse generator) を取り付けたロール周速度計とからなつて おり，その詳細についてはすでに2 章で述べてある.

一方, 圧延潤滑油の流量と濃度の可変装置には, Fig. 12 に示されるように, 潤滑油供給へッダーの直前でパー ム油（压延油）と温水を混合するスタティックミキサー (混合器) が用いられている. なお, 八幡 4 冷延では, パー ム油と温水を混合した 8 18\% 濃度の Oil in water 型 のエマルションが, 圧延ロールの手前約 $2 \mathrm{~m}$ 位置で鋼 板上に噴射されるダイレクト潤滑方式が採用されてい る. 従来の潤滑油供給方式は, ミキシングタンクで事前 に攪汼されたパーム油のエマルションが潤滑油供給へッ 


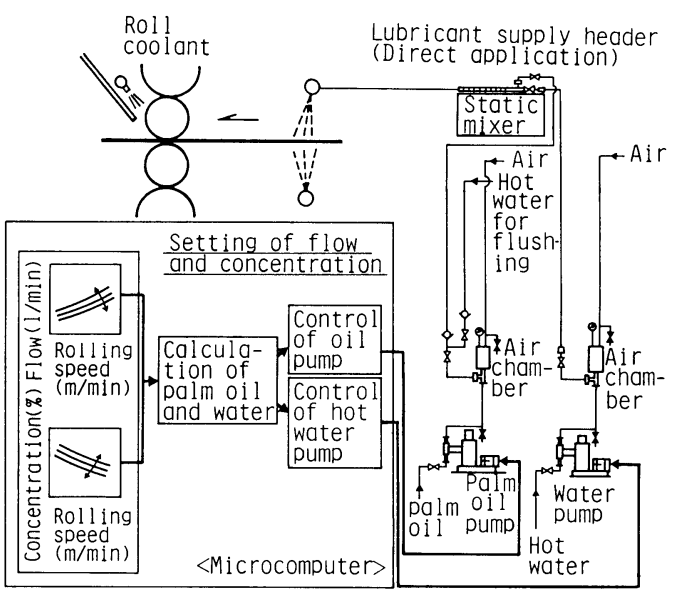

Fig. 12. Schematic diagram of lubricant control system.

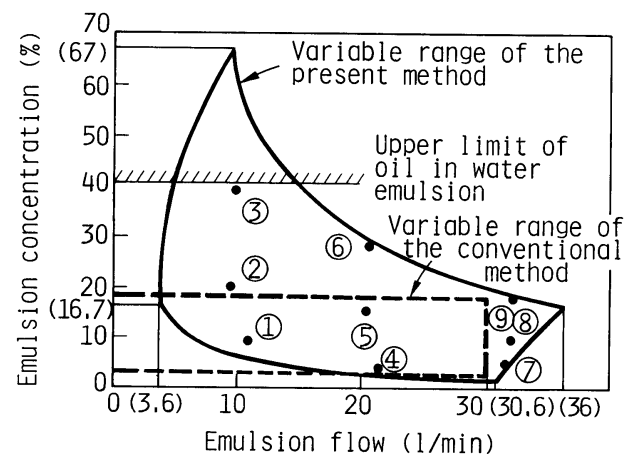

(1) (9): Checked points of emulsion properties

Fig. 13. Variable range of emulsion supply device.

ダーまで搬送されていたため，压延潤滑油の流量と濃度 を高応答で制御することが困難であつた．今回の方式で は，Fig. 12 に示されるように，パーム油と温水は潤滑 油供給へッダー直前まで別々に搬送され，供給へッダー から約 $6 \mathrm{~m}$ 前に設置されたスタティックミキサーで混 合されるため, 圧延潤滑油の流量と濃度を高応答で制御 することが可能である．Fig. 13 は，压延潤滑油の叮変 装置におけるポンプ流量とエマルション濃度の可変範囲 を示す。破線が従来の潤滑可変装置の叮変範囲で, 実線 がスタティックミキサーを用いた今回の可変範囲であ る. Fig. 14 は, Fig. 13 の 中に示した番号の位置で採 取したエマルションの乳化安定性を $\mathrm{ESI}^{18)}$ (Emulsion stability index）で示した四である。通常，ESI は0.6 以上で管理されており，スタティックミキサーを用いて も乳化安定性には問題がないことが分かる. Fig. 15 は,

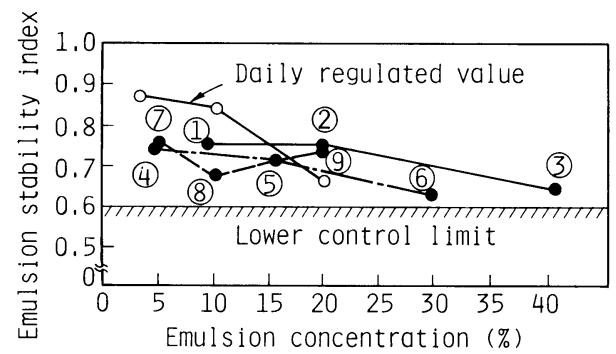

The number (1) - (9) corresponds to those in Fig. 13

Fig. 14. Relation between emultion stability index and emulsion concentration $\left(70^{\circ} \mathrm{C}\right)$.
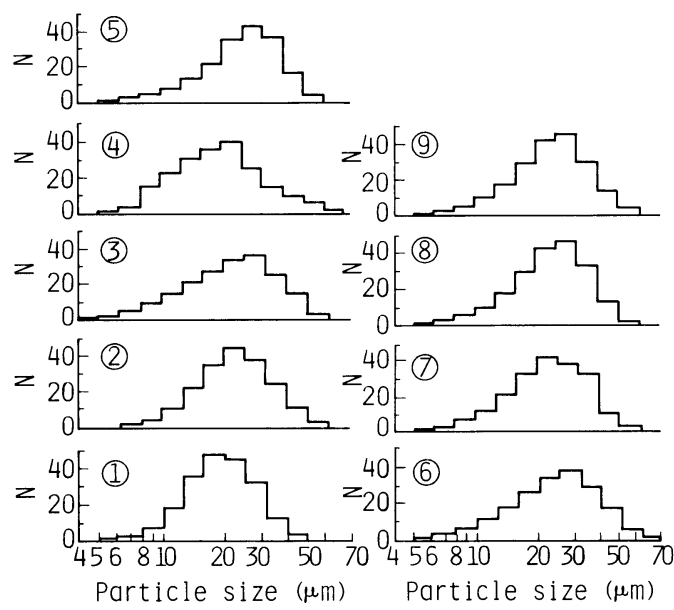

The number (1) (9) corresponds to those in Fig. 13

Fig. 15. Distribution of emulsion particle size.

Fig. 13 の中に示した番少位㯰で採取したエマルション の粒径分布を示す。従来のエマルションの中心粒径は

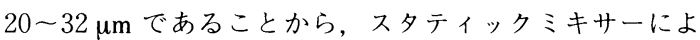
る方式は従来方式と同等である。

また，先進率制御システムでは，Fig. 12 に示してあ るように，压延速度によつて压延潤滑油の流量と濃度が 設定されると，3章で述べた先進率子測モデルによる先 進率制御によつて，定常压延時に 1 回から数回程度この 流量と濃度の設定値が調整される。なお，加減速压延時 あるいは定常压延に抢けるより短湖期の先進摔制御を可 能にするためには，极速度の変動が激しくても高い精度 で検出可能な板速度計が必要である.

\section{$4 \cdot 2$ 先進率制御効果}

圧延潤滑による先進率制御の効果を調べるために, $4 \cdot 1$ 節で述べた先進率制御装置を用い, Table 1 に示す 圧延条件で実験を行つた。その結果を Fig. 16 に示す。 
Table 1. Experimental conditions.
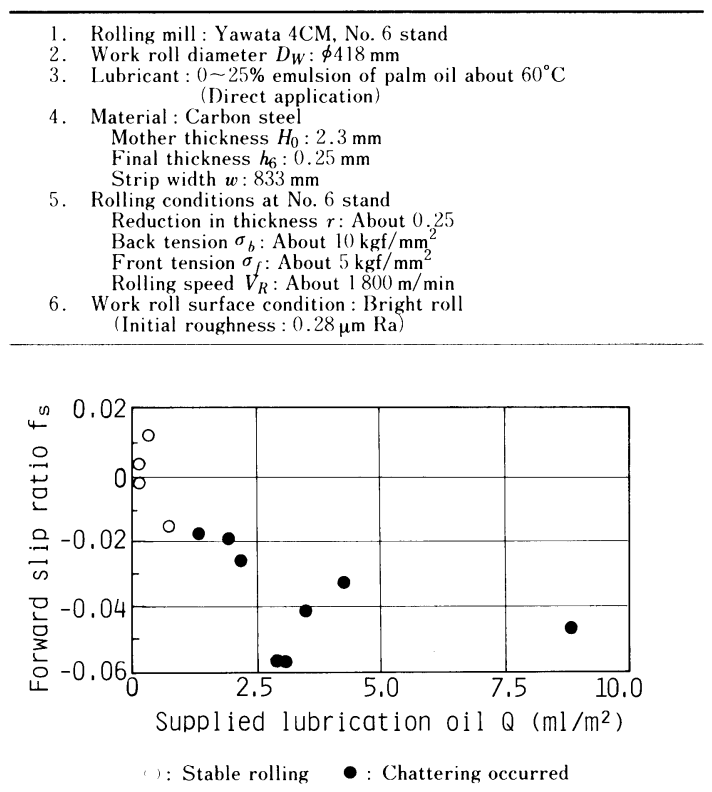

Fig. 16. Effect of supplied lubrication oil on forward slip ratio.

压延潤滑油量 (正味油量) $Q$ が $1 \mathrm{ml} / \mathrm{m}^{2}$ を越すと, 先進 率がー0.018 以下となつてチャタリングが発生した。 チャタリングの発生は第 6 スタンドの買竟で確認され,

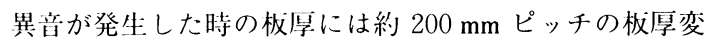
動が認められた。今回の実験から，第6スタンドにおけ る安定压延のための先進率の下限值はー0.015 程度で あることが判明した。また、今四開発した先進率制御シ ステムを第 6 スタンドに用い, 先進率の值を -0.015 以上に保つことによつて，チャタリングの発生率が著し く低減することが明らかになつた。

\section{5. 結言}

連続式冷間タンデムミルに扮いて高生産性機能を十分 に発揮できるようにするため, 死延潤消油の流量と濃度 とを高忍答で変更できる潤消供給装㯰を用いて，先進率 制御システムを開発した。この制御システムに組み込ま れている先進率子測モデルの特徵は, 以下に示すとおり である。（1）先進率が楅の場令でも取扱いができるよ うに，摩擦係数の計算にはスライド係数を用いて BLAND \& FORD の式を修正する力法を採用した。（2）摩擦係数 の予測式には, 有下率，压延入側の极厚，压延出側の板 厚, 後方張力, 前方張力および 2 次元平均変形抵抗に関 して一次式の形で，庄延速度，ロール替えからの压延し た長さ（または重量）および压延潤滑油量に関して指数
関数の形で重ね合わせた式を用いた。（3）2 次元平均 変形抵抗の予測式には, $n$ 乗則の項と圧延速度の項から なり，各項に含まれる係数を炭素当量，熱間圧延の仕上 げ温度および巻取温度で重回帰した形の式を使用した。

(4) 摩擦係数および 2 次元平均变形抵抗の予測式を用 いて推是した先進率は実測值とほほ 一致し，同様に推定した压延荷重は実測值と $\pm 10 \%$ の 精度で一致した。

また，制御システムに用いられている潤滑制御装置を 使つて行つた実験から，以下のことが明らかになつた.

(1) スタティックミキサーによつて得られるエマルショ ンは，乳化安定性および粒径分布のいずれにおいても従 来方式の場合と同等である.（2）压延安定性に及ぼす 圧延潤滑油量の効果の実験から, 八幡 4 冷延の第 6 ス夕 ンドにおける安定圧延のための先進率の下限值は一 0.015 程度である.

以上から，今回開発した先進率制御システムを用いて 压延潤滑油の供給量を調整することにより，チャタリン グの発生を防止した高速安定圧延の実現が可能となつ た.

\section{文献}

1 ) 御園生一長: 塑性と加工, 21 (1980), p. 1006

2 ) 梶原利幸, 藤野伸弘, 西 英俊, 志田 茂: 日立評論, 56 (1974), p. 3

3 ) 佐伯邦男, 橋本曾司: 塑性と加工, 19 (1968), p. 253

4 ) 水野高爾: 塑性と加工, 7 (1966), p. 383

5 ) 大森舜二, 堟本頴彦, 森本和夫, 飯伏順一, 川並高雄, 大矢 清, 山本普康: 第 32 回塑加連講論 (1981), p. 97

6 ) D. A. Bland and H. Ford: Proc. Instn. Mech. Eng., 159 (1948), p. 144

7 ) E. Orowan: Proc. Inst. Mech. Eng., 149 (1943), p. 10

8 ) 山本普康, 阿高松男, 中島浩衛: 塑性と加工, 23 (1982), p. 672

9 ) 山本普康, 柴田嘉基, 中島浩衛, 川並高雄: 塑性と加工, 24 (1983), p. 967

10）川並高雄, 中島浩衛, 山本普康, 土井公明, 大森舜二, 塚本頴彦, 梶原哲雄: 第 32 回塑加連講論 (1981), p. 93

11）小豆島明，金子徳次郎: 第 36 回塑加連講論 (1985), p. 33

12）中尾正和，高塚公郎: 板圧延の理論と実際（日本鉄鋼協会 編) (1984), p. 149

13) R. HiLl: The Mathematical Theory of Plasticity (1950), p. 209 [Clarendon Press]

14）美坂佳助: 塑性と加工，8 (1967), p. 188

15) J. H. HiтcHCOCK: Elastic Deformation of Rolls during Cold Rolling, Roll Neck Bearing (1935), p. 33 [ASME Research Publication]

16）五朽勇雄，木原䛨二: 日本金属学会誌，31（1967）, p. 368

17）例えば 赤坂 隆: 数值計算, 応用数学講座第 7 巻 (1978), p. 192

18) W. L. Roberts: Blast Furn. Steel Pl., 56 (1968), p. 382 